\section{Testing the Effects of Moisture on Seedcoat Color of Pinto Dry Beans}

\author{
Muharrem Ergun ${ }^{1}$, Ellen T. Paparozzi ${ }^{2}$, and Dermot P. Coyne \\ Department of Horticulture, University of Nebraska, Lincoln, NE 68583-0724 \\ Durward Smith \\ Departments of Horticulture and Food Science, University of Nebraska, \\ Lincoln, NE 68583-0919
}

Stephen Kachman

Department of Biometry, University of Nebraska, Lincoln, NE 68583-0712

\section{David S. Nuland \\ Panhandle Research and Extension Center, University of Nebraska, Scottsbluff, NE 69361-4939}

Additional index words. Phaseolus vulgaris, pod injury, testa, moistened filter paper test, yellowing

\begin{abstract}
Seedcoat color is an important trait, as it affects marketing and consumer acceptance of pinto beans (Phaseolus vulgaris L.). Pinto breeding line NE 94-4 showed seedcoat yellowing in on-farm field trials in Nebraska in 1996 and 1997. Hail, sprinkler irrigation, and fall rainfall appeared to be involved in increasing seedcoat yellowing, based on analysis of field and weather data of on-farm trial sites. The objective of this study was to determine the effect of moisture on seedcoat yellowing of pinto line NE 94-4 (susceptible) and pinto 'UI-114' (highly resistant). Two greenhouse experiments were conducted involving misting of bean plants near maturity and injecting water into maturing bean pods. Another experiment evaluated the response of seeds of these two bean entries to moisture by placing them on moist filter paper in petri dishes in the laboratory. Results showed that both genotype and moisture content are involved in seedcoat yellowing. This simple, cheap, and effective filter paper test was then used to evaluate seedcoat yellowing of nine pinto genotypes in response to moisture. Pinto NE 94-4 and 'Kodiak' showed the greatest change, while 'Bill Z' showed the least change, in seedcoat color.
\end{abstract}

Food legumes are grown and consumed in nearly all parts of the world. In many developing countries, $20 \%$ of the available protein is provided by legumes. Legumes are also an integral part of dietary protein for $\approx 50 \%$ of the world's population (Deshpande et al., 1984). Dry beans are produced in large quantities in South, Central, and North America; Mexico and east Africa (Singh, 1999). Pinto, great northern, and light red kidney beans are the main market classes produced in the central high plain states of Colorado, Nebraska, and Wyoming. Pinto ranks number one of all market classes of dry bean produced in the United States (Schwartz et al., 1996).

Seedcoat color is an important trait affecting marketing of pinto dry bean. Consumers prefer pinto cultivars with bright, shiny, mottled-colored seedcoat $\mathrm{s}$ and a bright yellow

Received for publication 30 May 2000. Accepted for publication 8 Sept. 2000. Nebraska Agricultural Research Division Series Number 13034. This paper is a part of the Master of Science thesis of M.E. The cost of publishing this paper was defrayed in part by the payment of page charges. Under postal regulations, this paper therefore must be hereby marked advertisement solely to indicate this fact.

${ }^{1}$ Current address: Horticulture Dept., Univ. of Florida, Gainesville, FL 32611.

${ }^{2}$ To whom reprint requests should be addressed. E-mail address: etp1@unl.edu hilum. Smith (1961) proposed the genotype for the pinto seedcoat color, now corresponding to the genic nomenclature of Prakken (1972), as $P C D J(G) B(v) R K . G$ and $v$ gene symbols in the above brackets were also recently assigned by M.J. Bassett, Florida State Univ., Gainesville (personal communication to D.P. Coyne, Feb. 2000). The pattern characteristic of the pinto seedcoat is controlled by a particular allele of the $C$ locus (not yet named) in place of the $\mathrm{M}$ symbol for this trait, formerly designated by Prakken (1974). Symbols for some genes controlling seedcoat color in common bean are: $P$, the basic gene for color to develop; $T$, necessary for a uniformly colored seedcoat ; $C$, a complex locus with different alleles and for constant mottling; $D$, the hilum ring factor; $J$, the shine factor; $G$, the yellowbrown factor; $B$, the gray-greenish brown factor; $V$, the violet factor; and $R k$, for reddish brown (Prakken, 1974).

Environmental conditions and diseases can cause seedcoat discoloration. Dry bean cultivars need to have the typical color of a particular market class and be free of off-type seeds and seed discoloration. In 1996, the pinto breeding line NE 94-4 was scheduled to be released due to a favorable combination of multiple disease resistance, upright plant habit, high yield, and seed quality. Nevertheless, NE 94-4 was not released because of yellow- ing of the seedcoat. This problem was not observed in lines selected in earlier generations under dry fall conditions.

Analysis of weather and field data (not presented) from the on-farm field trials indicated that hail, high temperature, rain, and sprinkler irrigation may have influenced the development of bean seedcoat yellowing. Studies were therefore designed to determine the influence of moisture and physical damage to pods on the degree of seedcoat yellowing of pinto NE 94-4 (susceptible) and pinto 'UI-114' (resistant). The latter is recognized in the trade as a standard for pinto seedcoat quality.

\section{Materials and Methods}

Misting experiment. The treatments, mist vs. control, were designed to simulate different conditions (no rain vs. rain and/or sprinkler irrigation) that can occur in the field during the last 2 weeks of the harvest season. Bean genotypes were planted in clay pots, volume $1450 \mathrm{~cm}^{3}$, on 22 Jan. 1998, in a horticulture research greenhouse, Lincoln, Nebr. The potting medium consisted of $27 \%$ vermiculite, $36 \%$ peat, $10 \%$ field soil, and $27 \%$ sand, by volume. After 3 weeks, half the seedlings were moved to another greenhouse, and placed on benches under a mist system. Plants were fertilized with $300 \mathrm{mg} \cdot \mathrm{L}^{-1}$ of $20 \mathrm{~N}-8.8 \mathrm{P}-16.6 \mathrm{~K}$ three times per week until pods formed; thereafter, nutrient applications were reduced to one per week. The greenhouse temperatures were $26^{\circ} \mathrm{C}$ day $/ 20^{\circ} \mathrm{C}$ night. The experimental design was a split-plot with the main plots blocked by both row and column within the greenhouse. The main plot factor was mist. The sub-plot treatments were pinto breeding line NE 94-4 and cultivar UI 114 (control). An individual sub-plot consisted of two plants per treatment combination with nine replications for a total of 72 plants. The treatments were applied 2 weeks before physiological maturity. The mist treatment was applied for 60 $\mathrm{min} / \mathrm{d}$ (a total of $302.8 \mathrm{~L}$ water applied). One sub-plot (two plants) was removed from each replication for misting. The misted plants were separated from the rest of the plants with plastic shields. After every misting, plants were moved back to their original places. Each misted pot was covered with a plastic bag to prevent water leaking into the potting medium. Six seeds were taken from four pods, harvested from the bottom to the upper parts of each plant $2 \mathrm{~d}$ after completion of the misting treatments. This technique allowed the samples to reflect variation in pod maturity and moisture. Yellowing was recorded for one to six seeds per pod. For analysis purposes, percentage of yellowing was defined as the average percentage of yellowing for the four plants in a plot.

Injection experiment. The influence of physical damage to the pod, along with the penetration of water into the pod on yellowing of the seedcoat, was determined. The plants were grown at the same time, and under the same conditions as the misting experiment. The experiment design was a randomized 
complete block with 12 replications. Bean genotypes 'UI 114' and NE 94-4 were used as blocks. A total of 72 plants were grown. On 27 Mar. 1998, 15 d before physiological maturity, the treatments were applied to the pods. Three pods were selected from the base, middle, and upper parts of each plant for each of three treatments. For the injury-only treatment, a hypodermic syringe was inserted into each pod near the pedicel. For the injection with water treatment, a hypodermic syringe was used to inject $5 \mathrm{~mL}$ of deionized water into the pod through the pod suture near the pedicel. After $15 \mathrm{~d}$, the percentage of yellowing of seeds from each of the three pods per plant was recorded.

Moistened filter paper experiments. This experiment was conducted in the laboratory during Apr. 1998. The design was a randomized complete block with four replications. Pinto 'UI 114' and NE 94-4 were arranged in blocks. The two treatments consisted of dry seeds placed on either moistened or dry (control) filter paper in petri dishes. Pods were randomly selected from control plants in the injection experiment described previously. Each pod was opened in the dark. The seed was extracted and placed immediately in a petri dish. Twenty seeds were placed on either moist or dry filter paper in each dish. The petri dishes were then sealed with tape to prevent air exchange, and kept in the dark during the experiment at $21{ }^{\circ} \mathrm{C}$. The percentage of seedcoat yellowing was recorded $7 \mathrm{~d}$ after the initiation of the experiment.

A second moistened filter paper experiment was performed to evaluate diverse pinto bean germplasm for seedcoat yellowing. Eight pinto cultivars and breeding line NE 94-4 were evaluated for the response to seedcoat yellowing in the presence of moisture, using the same procedure developed in the moistened filter paper experiment described above. The experimental design was a randomized complete block with two replications. Twenty seeds of each bean genotype were placed on moistened filter paper per petri dish per replicate, and on dry filter paper for the control treatment. Color of seeds was recorded $7 \mathrm{~d}$ after initiation of the experiment.

Measurement of seedcoat yellowing and statistical analysis. Yellowing was recorded visually by determining the percentage of the yellow area on a bean seed in the experiments. A scale from $0 \%$ to $100 \%$, measured in $10 \%$ intervals, was used. The mixed model procedure (Littel et al., 1996) was used to obtain appropriate statistical estimates and to test data in all three experiments.

Color, value (lightness), and chroma (strength) of the seeds of each of the pinto entries in the moistened filter paper germplasm experiment were recorded as described in the Munsell ${ }^{\mathrm{TM}}$ Book of Color (1929-42 pocket edition; Munsell Color Co., Baltimore). The color, value, and chroma are read together to give a description of the color and how it changes. In general, for value, the higher the number, the lighter the shade of color. For chroma, the lower the number, the stronger or deeper the shade.
The data showed no variation within each variety. Thus, the means of the control and moisture treatment as separated by genotypes were the only values examined and presented. No statistical analysis was necessary.

\section{Results and Discussion}

Misting experiment. Both the cultivar/ breeding line effect, (Type III $\mathrm{F}$ value $=$ $6.70, P \leq 0.0125)$ and the interaction between cultivar/breeding line and pod were significant $($ Type III F value $=2.63, P \leq 0.0512)$ such that NE 94-4 seeds showed a higher

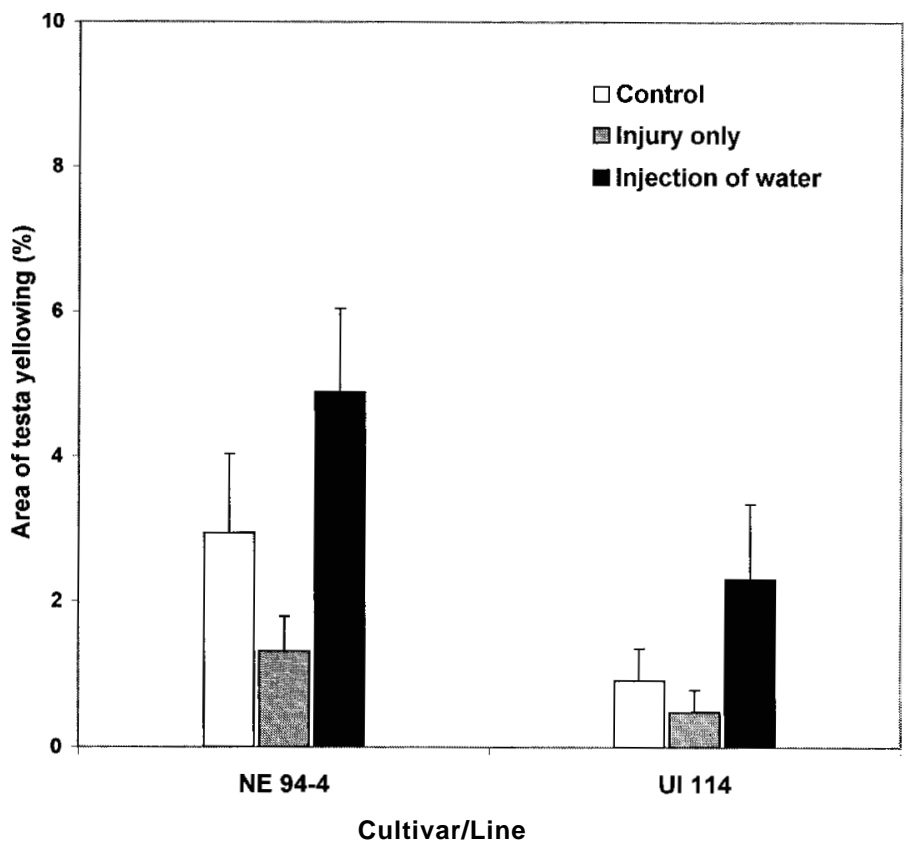

Fig. 1. Effect of injection of water on the percentage of seedcoat yellowing of two bean genotypes under the three different treatments. Means differed significantly within cultivar/lines at $P \leq 0.0238$ and represent 12 replications per treatment. Vertical bars $=\mathrm{SE}$.

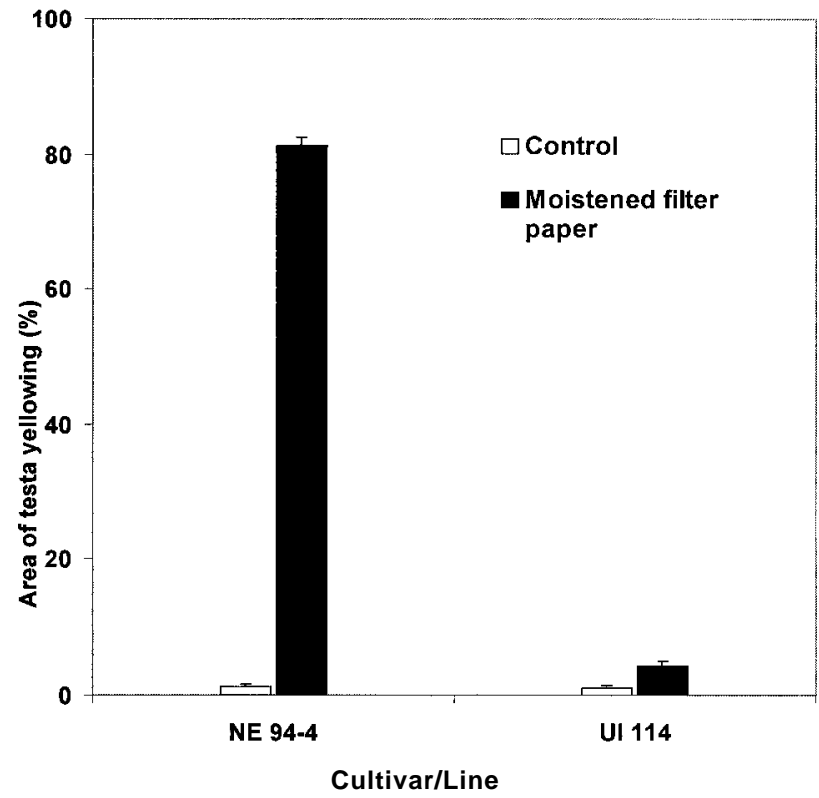

Fig. 2. Percentage of seedcoat yellowing of the two bean entries under two different treatments (control, moistened) in the moistened filter paper experiment. Means differed significantly within cultivars/ lines at $P \leq 0.001$ and represent four replications per treatment. Vertical bars $=\mathrm{SE}$. 
Injection experiment. When pods were injected with water, NE94-4 again showed more seedcoat yellowing than did 'UI 114' (Fig. 1; Type III $\mathrm{F}$ value $=4.01, P \leq 0.0238$ ). The water injection treatment was associated with more seedcoat yellowing than occurred in control seeds. The mechanism causing the change in seed color pigmentation in the presence of moisture is unknown.

Moistened filter paper experiments. Seeds placed directly on the moist filter papers showed some yellowing after $1 \mathrm{~d}$. Yellowing became more extensive after $3 \mathrm{~d}$ with NE 94-4 developing more seedcoat yellowing than 'UI 114' (Type III F value $=2518.010$, $P \leq 0.0001)$. The seeds of NE $94-4$ on moistened filter paper yellowed more (80\%; Fig. 2) than those taken from the pods injected with water (5\%; Fig. 1), or from those pods which were exposed to mist in the greenhouse $(8.5 \%$; data not shown). The difference in yellowing may be due to the more uniform contact between the seed and moisture in the petri dishes, while in the other two cases the seeds matured in the presence of moisture, and dried down. In the misting experiment and the field, seeds were shielded from moisture by the pods.

Seedcoat discoloration may result from other factors, such as storage. Certain pinto genotypes such as 'Chase' tend to develop a brownish color when stored dry for a long time. Light exposure and temperature may also interact with moisture and genotypes to cause seedcoat discoloration (Hughes and Sandsted, 1975). However, these two factors were held constant in our studies.

A combination of base color, value (lightness), and chroma (strength) in combination was used to describe the color of each bean genotype. Seeds of NE 94-4 and 'Kodiak' showed the most pronounced color changes in the moistened filter paper test (Table 1). NE
Table 1. Differentiation of seedcoat color traits of pinto bean genotypes in response to moisture using the moistened filter paper test. A statistical analysis of data was not carried out because no variation was observed.

\begin{tabular}{lcccc}
\hline Cultivar/breeding line & Treatment & Color description & Value $^{\mathrm{y}}$ & Chroma $^{\mathrm{x}}$ \\
\hline Bill Z $^{\mathrm{w}}$ & Moisture & Yellowish yellow-red & 8 & 2 \\
& Control & Yellowish yellow-red & 8 & 2 \\
Kodiak $^{\mathrm{v}}$ & Moisture & Yellow-red & 6 & 10 \\
& Control & Yellow-red & 5 & 8 \\
Apache $^{\mathrm{u}}$ & Moisture & Yellow-red-yellow & 8 & 4 \\
& Control & Yellowish yellow-red & 8 & 2 \\
Chase $^{\mathrm{t}}$ & Moisture & Yellow-red-yellow & 8 & 4 \\
& Control & Yellowish yellow-red & 8 & 2 \\
Vision $^{\mathrm{s}}$ & Moisture & Yellow-red-yellow & 8 & 4 \\
& Control & Yellowish yellow-red & 8 & 2 \\
Rogers 179 $^{\mathrm{r}}$ & Moisture & Yellow-red-yellow & 7 & 2 \\
& Control & Yellowish yellow-red & 8 & 2 \\
NE 94-4 & Moisture & Yellow-red-yellow & 6 & 4 \\
& Control & Yellow-red & 8 & 2 \\
Buckskin & Moisture & Yellow-red-yellow & 8 & 4 \\
& Control & Yellowish yellow-red & 8 & 2 \\
UI 114 & Moisture & Yellow-red-yellow & 8 & 4 \\
& Control & Yellowish yellow-red & 8 & 2 \\
\hline
\end{tabular}

${ }^{2}$ Munsell $^{\text {TM }}$ Book of Color, 1929-42, pocket edition (Munsell Color Co., Baltimore).

${ }^{y}$ The color, value, and chroma are read together to give a description of the color and how it changes. For value, the higher the number, the lighter the shade of color.

${ }^{x}$ For chroma, the lower the number the stronger or deeper the shade.

${ }^{\text {w} C o l o r a d o ~ S t a t e ~ U n i v ., ~ F o r t ~ C o l l i n s . ~}$

"Michigan State Univ., East Lansing.

"Idaho Seed Bean, Twin Falls, Idaho.

'Univ. of Nebraska, Lincoln.

Seminis-Asgrow, Twin Falls, Idaho.

'Novartis-Rogers Bros., Nampa, Idaho.

qUniv. of Idaho, Kimberly.
94-4 changed from a pale beige and became more yellow with a touch brown as shown by a decrease in lightness (value) and an increase in strength of the color (chroma), while 'Kodiak' became more red with a significant increase in the strength of the color. The cultivar BillZ showed the least change in seedcoat color in response to moisture, a trait highly desired by bean growers, processors, and consumers. The lightness (value) of seeds of 'Apache', 'Chase', 'Vision', 'Buckskin', and 'UI-114' did not change in the presence of moisture, but all of these genotypes showed an increased in strength of the color (a shift from pale beige to tan). These results again confirmed that the presence of moisture on mature pinto seeds caused seedcoat yellowing on susceptible lines. We recommend that the moistened filter paper test be used by researchers to detect lines that are susceptible to seedcoat yellowing in response to moisture.

\section{Literature Cited}

Deshpande, S., S.K. Satyhe, and D.K. Salunkhe. 1984. Interrelationships between certain physical and chemical properties of dry bean. Qual. Plant Foods Hum. Nutr. 34:53-65.

Hughes, P.A. and R.F. Sandsted. 1975. Effect of temperature, relative humidity, and light on the color of 'California Light Red Kidney' bean during storage. HortScience 10:421-423.

Littell, R.C., G.A. Milliken, W.W. Stroup, and R.D. Wolfinger. 1996. SAS system for mixed models. SAS Inst., Cary, N.C.

Munsell Color Co., Inc. 1929-42. Munsell ${ }^{\mathrm{TM}}$ book of color, pocket ed. Munsell Color Co., Baltimore.

Prakken, R. 1972. Inheritance of colors in Phaseolus vulgaris. III. On genes for red seed coat colors and a general synthesis. Medelingen Landbouwhogeschool, Wageningen, The Netherlands.

Prakken, R. 1974. Inheritance of colors in Phaseolus vulgaris L. IV. Recombination within the "complex locus C'. Medelingen Landbouwhogeschool, Wageningen, The Netherlands.

Schwartz, H.F., M.A. Brick, D.S. Nuland, and D.B. Franc. 1996. Dry bean production and pest management. Reg. Bul. 562A. Coop. Ext. Res. Ctr., Colo. State Univ., Fort Collins.

Singh, S.P. 1999. Production and utilization, p. 124. In: S.P. Singh (ed.). Common bean improvement in the twenty-first century. Developments in plant breeding Vol. 7. Kluwer Acad., Dordrecht, The Netherlands.

Smith, F.L. 1961. Seed-coat color genes in six commercial varieties of beans. Hilgardia 31:1-14. 